J. Clin. Chem. Clin. Biochem.

Vol. 16, 1978, pp. 223-224

\title{
Influence of Monoethanolamine on Activity Measurements of the Isoenzymes of Alkaline Phosphatase
}

\author{
By K. Jung, Monika Pergande, G. Reichmann, A. Sitte and E. Egger \\ Department of Clinical Biochemistry, Charité, Humboldt University Berlin
}

(Received June 30/September 24, 1977)

Summary: Monoethanolamine, a frequent impurity of diethanolamine, inhibits the activity of the isoenzymes of alkaline phosphatase to various extents. Isoenzymes from liver and bone, in particular, are strongly inhibited. Inhibition is stronger at lower $\left(25^{\circ} \mathrm{C}\right)$ than at higher temperatures $\left(37^{\circ} \mathrm{C}\right)$.

\section{Zum Einfluß von Monoethanolamin auf die Aktivitätsbestimmung der Isoenzyme der alkalischen Phosphatase}

Zusammenfassung: Monoethanolamin als häufige Verunreinigung von Diethanolamin hemmt die Aktivität der Isoenzyme der alkalischen Phosphatase in unterschiedlichem Ausmaß. Besonders stark gehemmt werden die Isoenzyme von Leber und Knochen. Die Hemmung ist bei niedrigen Meßtemperaturen $\left(25^{\circ} \mathrm{C}\right)$ stärker als bei höheren $\left(37^{\circ} \mathrm{C}\right)$.

In various countries (e. g. Federal Republic of Germany, Scandinavian countries) the activity measurement of alkaline phosphatase (orthophosphoric monoester phosphohydrolase, EC 3.1.3.1) with diethanolamine buffer is recommended as a standardised method $(1,2)$. This enzyme activity was hitherto measured chiefly in glycine buffer, but the activities measured in diethanolamine buffer are much higher, because the transphosphorylase reaction is measured in addition to the hydrolytic phosphatase $(3,4,5)$. The reliability of this method of measuring the activity of alkaline phosphatase is, however, impaired by monoethanolamine, which may occur as an impurity in diethanolamine and acts as an inhibitor of alkaline phosphatase $(6,7)$. The aim of this study is to show the different influence of monoethanolamine on the activity of the various isoenzymes of alkaline phosphatase.

\section{Methods and Materials}

Kinetic measurements of enzyme reaction velocity wejre performed on an Eppendorf photometer (with recorder) at $405 \mathrm{~nm}$ and $30^{\circ} \mathrm{C}$. Final concentrations in the mixture were $1 \mathrm{~mol} / 1$ diethanolamine ( $\mathrm{pH} 9.8$ ), $0.5 \mathrm{mmol} / \mathrm{l} \mathrm{MgCl}_{2}, 10 \mathrm{mmol} / \mathrm{l} 4-$ nitrophenylphosphate and the monoethanolamine concentrations given below. Ratio of sample volume to final volume was $1: 66$. The reaction was started by addition of 4-nitrophenylphosphate. The rate of increase in absorbance was monitored continuously. The enzyme activities were calculated: from the reaction rates in the first two minutes and are mean values of double or triple measurements. The precision within series (SD) for a serum of $168.4 \mathrm{U} / 1$ was characterised by SD of $1.77 \mathrm{U} / 1(\mathrm{n}=10)$. Isoenzymes of alkaline phosphatase prepared from bones, liver and small intestine according to Gerhardt et al. (8) were used for the investigation. The placental isoenzyme was obtained by homogenisation of placenta in $150 \mathrm{mmol} / \mathrm{l} \mathrm{Tris} / \mathrm{HCl}$ buffer (pH 7.5) and $1 \mathrm{mmol} / 1 \mathrm{MgCl}_{2}$ and by centrifugation for $15 \mathrm{~min}$ at $20.000 \mathrm{~g}$ at $4^{\circ} \mathrm{C}$. The isoenzymes were added to inactivated serum ( $30 \mathrm{~min}, 65^{\circ} \mathrm{C}$; no residual phosphatase activity). Commercial diethanolamine was distilled on a column under vacuum. The main fraction contained $99.8 \%$ diethanolamine, $0.2 \%$ triethanolamine; the monoethanolamine content was below $0.01 \%$ (gas chromatographic analysis as trifluoroacetyl compound; Varian gas chromatograph). 4-nitrophenylphosphate and triethanolamine hydrochloride were products of Boehringer, Mannheim; $\mathrm{MgCl}_{2}$, and monoethanolamine $(94.7 \%$ monoethanolamine, $5.3 \%$ diethanolamine) were obtained from Laborchemie Apolda.

\section{Results and Discussion}

In checking the diethanolamine from various producers, Bowers (6) found activities of alkaline phosphatase between 82 and $100 \%$ and interpreted this as the influence of monoethanolamine. We measured the activities of the various isoenzymes of alkaline phosphatase in dependence on monoethanolamine concentration in the test mixture. Monoethanolamine impurity was simulated by adding monoethanolamine to monoethanolaminefree diethanolamine. Concentrations of 1 to $60 \mathrm{mmol} / 1$ monoethanolamine corresponding to a content of 0.1 to $6 \%$ monoethanolamine in diethanolamine were tested at a final concentration of $1 \mathrm{~mol} / \mathrm{l}$ in the test mixture (fig. 1). A monoethanolamine concentration of $<5 \mathrm{mmol} / 1$ in the test mixture inhibits the isoenzymes of alkaline phosphatase, the various iso- 


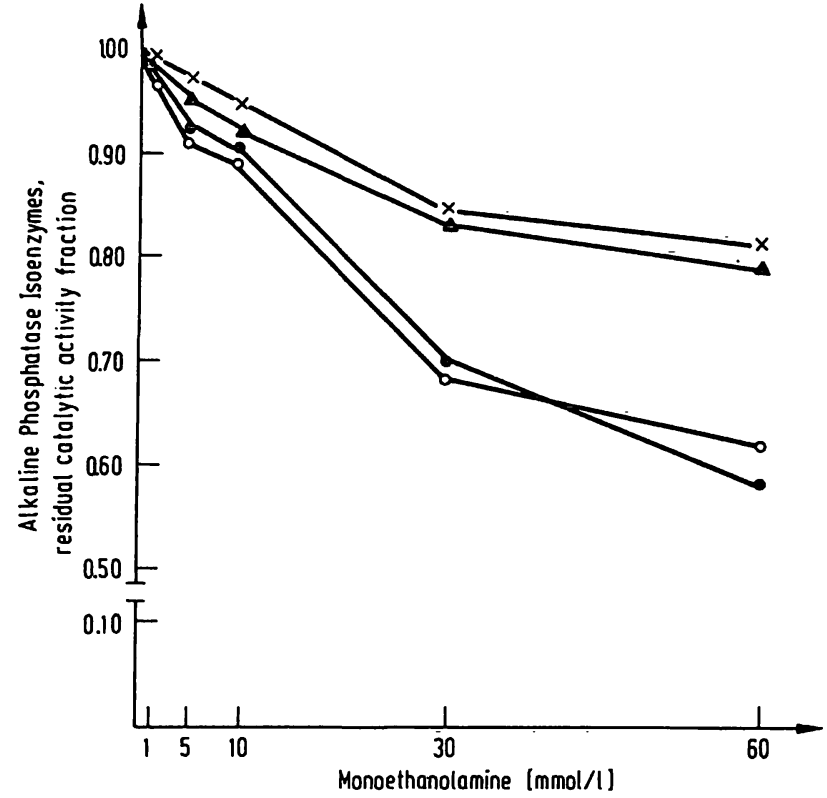

Fig. 1. Influence of monoethanolamine concentration on catalytic activity of the isoenzymes of alkaline phosphatase.

Conditions are given in the text; each point is the mean of duplicate or triplicate. Isoenzymes prepared according to Gerhardt et al. (8) were added to inactivated serum. Catalytic activity in diethanolamine buffer with monoethanolamine impurity is expressed as fraction of that obtained in diethanolamine buffer without monoethanolamine: small intestine $272.2 \mathrm{U} / 1 \mathrm{X}-\mathrm{X}$; bone $310.1 \mathrm{U} / 1 \bullet-\bullet$; liver $118.2 \mathrm{U} / 10 \longrightarrow 0$; placenta $297.7 \mathrm{U} / 1 \Delta \longrightarrow$

enzymes being influenced to different extents. In particular the isoenzymes from liver and bone are inhibited, while the activities of isoenzymes from small intestine and placenta are less impaired. This different influence of monoethanolamine is noteworthy, because monoethanolamine may not only result in a falsely low value, it may lead to the recording of a false relationship between isoenzyme activities.

The extent of monoethanolamine inhibition of the isoenzymes of alkaline phosphatase is, to a considerable extent, determined by the assay temperature. In comparative investigations of monoethanolamine

\section{References}

1. Empfehlungen der Deutschen Gesellschaft für Klinische Chemie (1972), this J. 10, 182-192.

2. Committee on Enzymes of the Scandinavian Society for Clinical Chemistry and Clinical Physiology (1974), Scand. J. Clin. Lab. Invest. 33, 291-306.

3. Amador, E. (1972), Clin. Chem. 18, 94.

4. McComb, R. B. \& Bowers, G. N. (1972), Clin. Chem. 18,' 97-104.

5. Zech, R., Grote, M., Zürcher, K. \& Schlaeger, R. (1973), this J. 11, 461-464.

6. Bowers, G. N. (1975), in Quality Control in Clinical Chemistry, Transactions of the VI th International Symposium Geneva (Anido, G., Rosalki, S. B., Van Kampen, E. J. \& Rubin, M., eds.), p. 441-465, Walter de Gruyter, Berlin.

7. Viitala, A. J., Jokela, H. A., Penttilä, I. M. \& Nummi, S. (1975), Scand. J. Clin. Lab. Invest. 35, 267-273.
Tab. 1. Influence of assay temperature on the monoethanolamine inhibition of the isoenzymes of alkaline phosphatase. Measurements were made as described in the text; $60 \mathrm{mmol} / 1 \mathrm{monoethanolamine}$ as final concentration in the test mixture. Catalytic activity is expressed as fraction (mean \pm S.D., $n=3$ ) of that obtained in diethanolamine buffer without monoethanolamine; at $25^{\circ} \mathrm{C}$ and $37^{\circ} \mathrm{C}$ (in brackets), respectively: small intestine $252.3 \mathrm{U} / 1$ (337.7 U/l); bone $248.7 \mathrm{U} / \mathrm{l}(375.7 \mathrm{U} / 1)$; liver $96.7 \mathrm{U} / \mathrm{i}(151 \mathrm{U} / 1)$; placenta $210 \mathrm{U} / 1(364.8 \mathrm{U} / 1)$. Statistical evaluation was performed by means of $t$-test.

\begin{tabular}{|c|c|c|c|}
\hline & fracti & $37^{\circ} \mathrm{C}$ & significance \\
\hline $\begin{array}{l}\text { small intestine } \\
\text { bone } \\
\text { liver } \\
\text { placenta }\end{array}$ & $\begin{array}{l}0.811 \pm 0.004 \\
0.584 \pm 0.004 \\
0.619 \pm 0.003 \\
0.790 \pm 0.008\end{array}$ & $\begin{array}{l}0.875 \pm 0.006 \\
0.650 \pm 0.007 \\
0.672 \pm 0.011 \\
0.883 \pm 0.005\end{array}$ & $\begin{array}{l}p<0.001 \\
p<0.001 \\
p<0.01 \\
p<0.001\end{array}$ \\
\hline
\end{tabular}

inhibition, there were significant differences in the inhibition due to monoethanolamine depending on the assay temperature (tab. 1). The inhibition at $25^{\circ} \mathrm{C}$ is greater than that observed at $37^{\circ} \mathrm{C}$. In the case of a recently recommended conversion of activities measured at different assay temperatures (9), this could lead to a considerable error, depending on the isoenzyme composition of serum.

Additions of triethanolamine up to a concentration of $40 \mathrm{mmol} / 1$ to the test solution, i. e. up to a content of $4 \%$ triethanolamine in $1 \mathrm{~mol} / \mathrm{l}$ diethanolamine, had no influence on determined activities.

Gas chromatographic analysis of diethanolamine samples from three reputable chemical producers, showed impurities of $1.5,5.8$ and $6.4 \%$ monoethanolamine. This shows clearly that an undistilled and unchecked commercial product should never be used for preparation of the diethanolamine buffer. As a gas chromatographic assay of purity seems to be unavoidable, the production of the necessary buffer solutions by laboratories would be inconvenient. For measuring alkaline phosphatase and alkaline phosphatase isoenzymes by means of diethanolamine buffer, only checked test combinations should therefore be used.

8. Gerhardt, W., Nielsen, M. L., Nielsen, O. N., Olsen, J. S. \& Statland, B. E. (1974), Clin. Chim. Acta 53, 281-290.

9. Stạehler, F., Gruber, W., Stoltz, M. \& Kessler, A. (1976), 2nd European Congress on Clinical Chemistry Prague.

Dr. K. Jung,

Ing. Monika Pergande,

Dipl.-Chem. G. Reichmann,

Dr. A. Sitte,

Prof. Dr. E. Egger,

Abteilung Klinische Biochemie des Bereichs Medizin (Charité) und Lehrstuhl Pathologișche Biochemie der Humboldt-Universität żu Berlin,

Schumannstr. 20/21

104 Berlin

DDR-104 Berlin 